九州大学学術情報リポジトリ

Kyushu University Institutional Repository

Observation on the Male 10th Abdominal Segment in Deltocephalini, Paralimnini and Their Allied Tribes (Homoptera: Cicadellidae:

Del tocephalinae)

Kamitani, Satoshi

https://doi.org/10.5109/2627

出版情報: ESAKIA. 38，pp. 105-112，1998-03-31. Entomological Laboratory，Faculty of Agriculture, Kyushu University バージョン：

権利関係 : 


\title{
Observation on the Male 10th Abdominal Segment in Deltocephalini, Paralimnini and Their Allied Tribes (Homoptera: Cicadellidae: Deltocephalinae) ${ }^{1,2)}$
}

\author{
Satoshi Kamitani \\ Entomological Laboratory, Faculty of Agriculture, \\ Kyushu University, Fukuoka, 8 12-858 1 Japan
}

\begin{abstract}
The male 10th abdominal segment of Cicadellidae was investigated for 42 species belonging to 13 tribes of Deltocephalinae and 6 to 5 allied subfamilies. The typical 3 states are recognized; fully sclerotized, partly membranous and fully membranous. The 10th segment is fully sclerotized in most species of Deltocephalinae including Paralimnini, partly membranous in the allied subfamilies, and fully membranous in Macrostelini and some species of Deltocephalini.
\end{abstract}

Key words: Deltocephalini, Paralimnini, Cicadellidae, morphology, abdomen.

\section{Introduction}

This paper is the second part of the morphological study on Deltocephalini and Paralimnini (Kamitani 1997). Knight \& Webb (1993) studied the phylogenetic relationships between genera of Macrostelini, and compared them with 28 species of other deltocephaline tribes as the outgroup. They observed 81 morphological characters including the membranization of the male 10th abdominal segment, and recognized 2 states; sclerotized at least in part and membranous. The membranization of the postgenital segment was treated as one of the synapomorphies of Macrostelini, but this character state is also shared by some other genera of Deltocephalini. In order to clarify the distributional pattern of this postgenital character state in Deltocephalini and its closely related tribe Paralimnini, 42 deltocephaline species and 6 species belonging to 5 allied subfamilies were investigated.

1) Contribution from the Entomological Laboratory, Faculty of Agriculture, Kyushu University, Fukuoka (Ser. 5, No. 8).

2) This work was partly supported by a Grant-in-Aid from the Ministry of Education, Science, Sports and Culture, Japan (C(2)09839021). 


\section{Materials and methods}

The 10th abdominal segment of dried male specimens was dissected. The species examined in this paper were same as those used in the previous study (Kamitani 1997); Deltocephalini: Alobaldia tobae, Deltocephalus pulicaris, Endria inimica, Futasujinus candidus, Hengchunia koshuensis, Recilia coronifer, $R$. dorsalis, R. oryzae, Takagiella tezuyae, Yanocephalus yanonis, Paralimnini: Diplocolenus evansii, Jassargus repletus, Metalimnus marmoratus, Paralaevicephalus nigrifemoratus, Paralimnus tamagawanus, Psammotettix striatus, Sorhoanus tritici, Doraturini: Aconurella orientalis, Doratura gravis, Athysanini: Albicostella kiushuensis, Exitianus fusconervosus, Handianus limbifer, Laburrus impictifrons, Matsumurella kogotensis, Nephotettix cincticeps, Orientus ishidae, Paramesodes albinervosus, Limotettix striola, Scleroracus jakowleffi, Balcluthini: Balclutha incisa, Cicadulini: Elymana sulphurella, Hecalini: Hecalus concentralis, Macrostelini: Macrosteles striifrons, Yamatotettix flavovittatus, Opsiini: Hishimonus sellatus, Platymetopiini: Phlogotettix cyclops, Scaphoideini: Scaphoideus albovittatus, S. festivus, Scaphytopiini: Japananus hyalinus, Stenometopiini: Doratulina (D.) producta, D. (Paivanana) indra, tribe incertae sedis: Amimenus mojiensis, Xestocephalinae: Xestocephalus iguchii, Iassinae: Batracomorphus mundus, Aphrodinae: Planaphrodes sahlbergi, Selenocephalinae: Drabescus nigrifemoratus, Parabolopona guttatus and Pentniminae: Penthimia nitida. The systematic positions of these species were relied upon the check list by Oman et al. (1990). The abdomen was steeped in $5 \%$ solution of $\mathrm{KOH}$, and warmed for 3 to 5 minutes until the organs became soft. After the treatment with potash, the materials were transferred to $25 \%$ solution of ethanol, and observed under a stereoscopic microscope.

\section{Results}

The following 3 states were observed in the species examined; fully sclerotized (Fig. 11), partly membranous (Fig. 21), and fully membranous (Fig. 1). The fully sclerotized state was observed in most species of Deltocephalinae. The partly membranous state was shared within the allied subfamilies. The fully membranous state occurred in Deltocephalini, Macrostelini, Doraturini and Athysanini.

\section{Deltocephalini (Figs. 1-10)}

The tribe Deltocephalini classified by Knight \& Webb (1993) has 2 character states; fully sclerotized and fully membranous. The 10th segment of Deltocephalus, the type genus of Deltocephalini, is fully membranous. The segment of Alobaldia, Endria and Recilia is also fully membranous. That of Futasujinus, Hengchunia, Takagiella and Yanocephalus are fully sclerotized. 


\section{Paralimnini (Figs. 1 1-17)}

This tribe exhibits a single state except for the genus Psammotettix. The segment of Paralimnus, the type genus, is entirely sclerotized, and that of Diplocolenus, Jassargus, Metalimnus, Paralaevicephalus and Sorhounus are also same. That of Psammotettix is partly membranous.

3. Doraturini (Figs. 18-19)

Doraturu is the type genus of this tribe, and the segment is fully membranous. The segment of Aconurella is fully sclerotized.

\section{Balcluthini (Fig. 30)}

Balclutha is the type genus of this tribe, and the segment is partly membranous.

5. Macrostelini (Figs. 33-34)

Macrosteles is the type genus of this tribe, and the segment of Macrosteles and Yumatotettix is fully membranous.

6. Other tribes and subfamilies (Figs. 20-29, 31-32, 35-47)

All other tribes of Deltocephalinae including Laburrus impictifrons exhibit fully sclerotized state except for some genera. The segment of Paramesodes is fully membranous. That of Exitianus, Scleroracus, Hecalus, Hishimonus and Doratulina (Paivanana) are partly sclerotized. All allied subfamilies show partly sclerotized state.

\section{Discussion}

The strong membranization of the 10th segment was observed in Paramesodes, 2 genera of Macrostelini, and 4 genera of Deltocephalini. This character state is hypothesized as the evolutionary novelty occurred several times in the 3 taxonomic units, or synapomorphy of these units.

The result of the observation on the pronotal carina (Kamitani 1997) suggested that there are 2 clades in the genera of Deltocephalini (sensu Oman et al. 1990). The distributional pattern of character states of the 10th segment is consistent with that of the pronotal carina. Therefore, it is also supported that there are 2 clades in Deltocephalini (sensu Oman et al. 1990). This membranization is a synapomorphy of the tribe Deltocephalini. Four genera with the fully sclerotized state, Futasujinus, Hengchunia, Tukagiella and Yanocephalus, should be classified into Paralimnini. 


\section{Acknowledgments}

I wish to express my sincere gratitude to Prof. J. Yukawa (Ent. Lab., Fac. Agr., Kyushu Univ., Fukuoka) for his directions. My cordial thanks are due to Prof. Emeritus K. Morimoto (Fukuoka City) for their critical review of the manuscript and helpful comments for the present study. I am much indebted to Assoc. Prof. M. Hayashi (Biol. Lab, Fac.Educ., Saitama Univ.), who read through the manuscript, gave me many kind suggestions and loaned many valuable specimens. I thank to Dr. S. Miyamoto (Fukuoka City) and Assoc. Prof. T. Yasunaga (Biol. Lab., Hokkaido Educ. Univ.) for their suggestions.

\section{References}

Kamitani, S., 1997. Observation on the lateral carinae of the pronotum in Paralimnini and its allied tribes (Homoptera, Cicadellidae, Deltocephalinae). Esakia, (37): 2533 .

Knight, W. J. \& M. D. Webb, 1993. The phylogenetic relationships between virus vector and other genera of macrosteline leafhoppers, including descriptions of new taxa (Homoptera: Cicadellidae: Deltocephalinae). Syst. Ent., 18: 1 1-55.

Oman, P. W., W. J. Knight \& M. W. Nielson, 1990. Leafhoppers (Cicadellidae): A Bibliography, Generic Check List und Index to the World Literature 1956 - 1985. 368 pp. C.A.B. Intern. Inst. Ent., Oxon. 

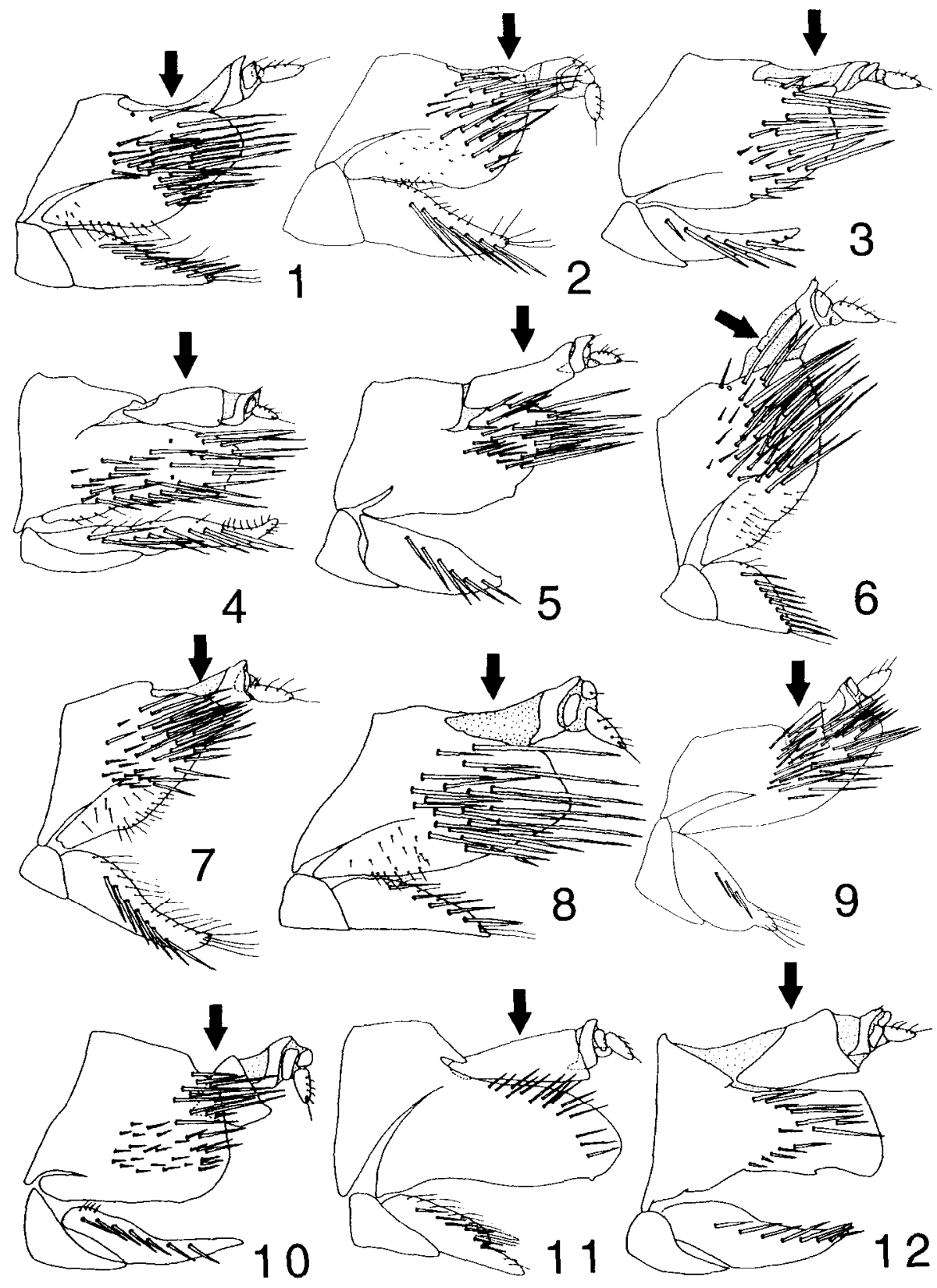

Figs. 1-12. Male genital and postgenital segments. 1, Alobaldiatobae; 2, Deltocephalus pulicaris; 3, Endria inimica; 4, Futasujinus candidus; 5, Hengchunia koshuensis; 6, Recilia coronifer; 7, R. dorsalis; 8, R. oryzae; 9, Takagiella tezuyae; 10, Yanocephalus yanonis; 11, Diplocolenus evansii; 12, Jassargus repletus. 


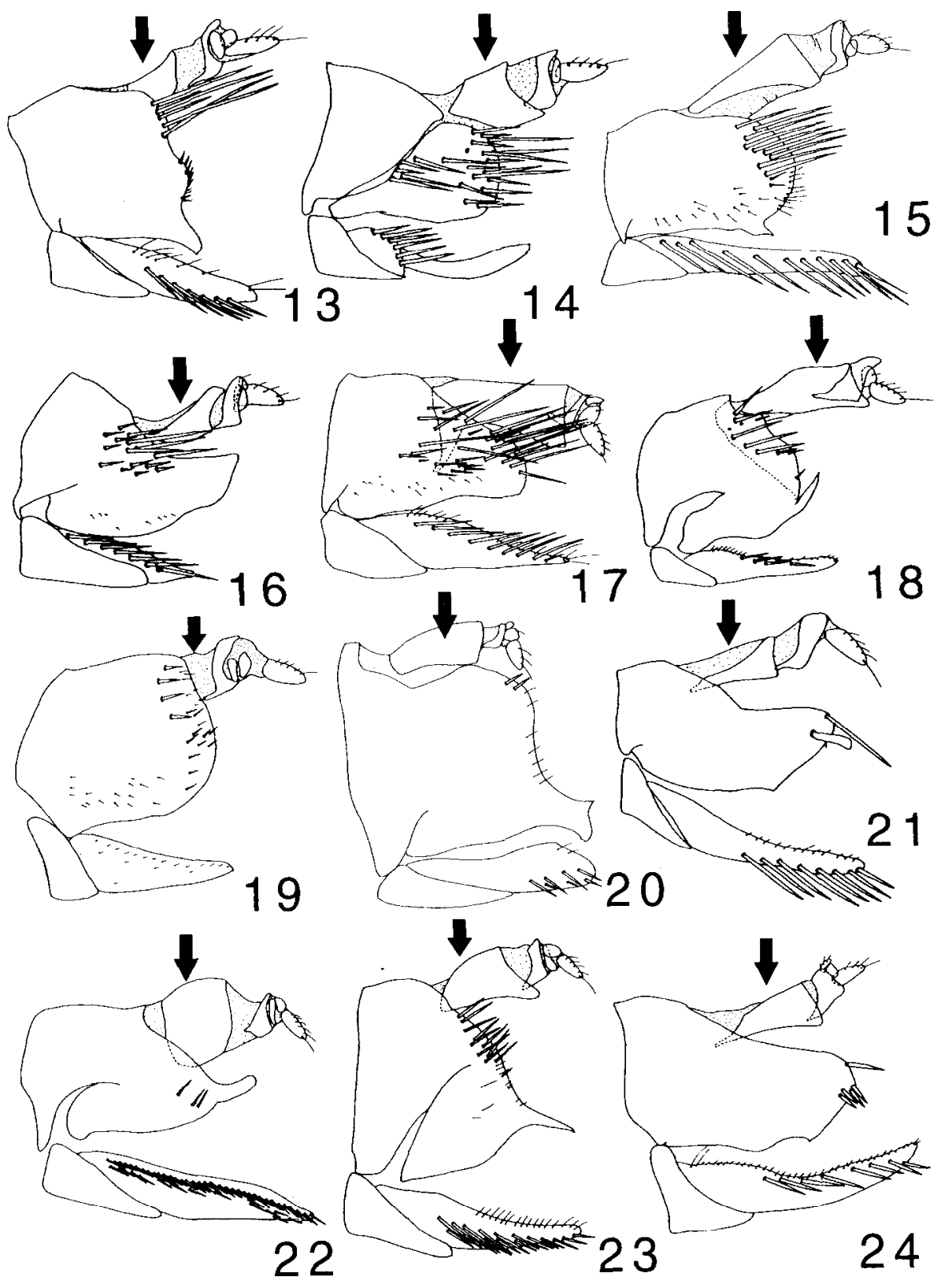

Figs. 13-24. Male genital and postgenital segments. 13, Metalimnus marmoratus; 14 , Paralaevicephalus nigrifemoratus; 15, Paralimnus tamagawanus; 16, Psammotettix striatus; 17, Sorhoanus tritici; 18, Aconurella orientalis; 19, Doratura gravis; 20, Albicostella kiushuensis; 2 1, Exitianus fusconervosus; 22, Handianus limbifer;23, Matsumurella kogotensis; 24, Nephotettix cincticeps. 

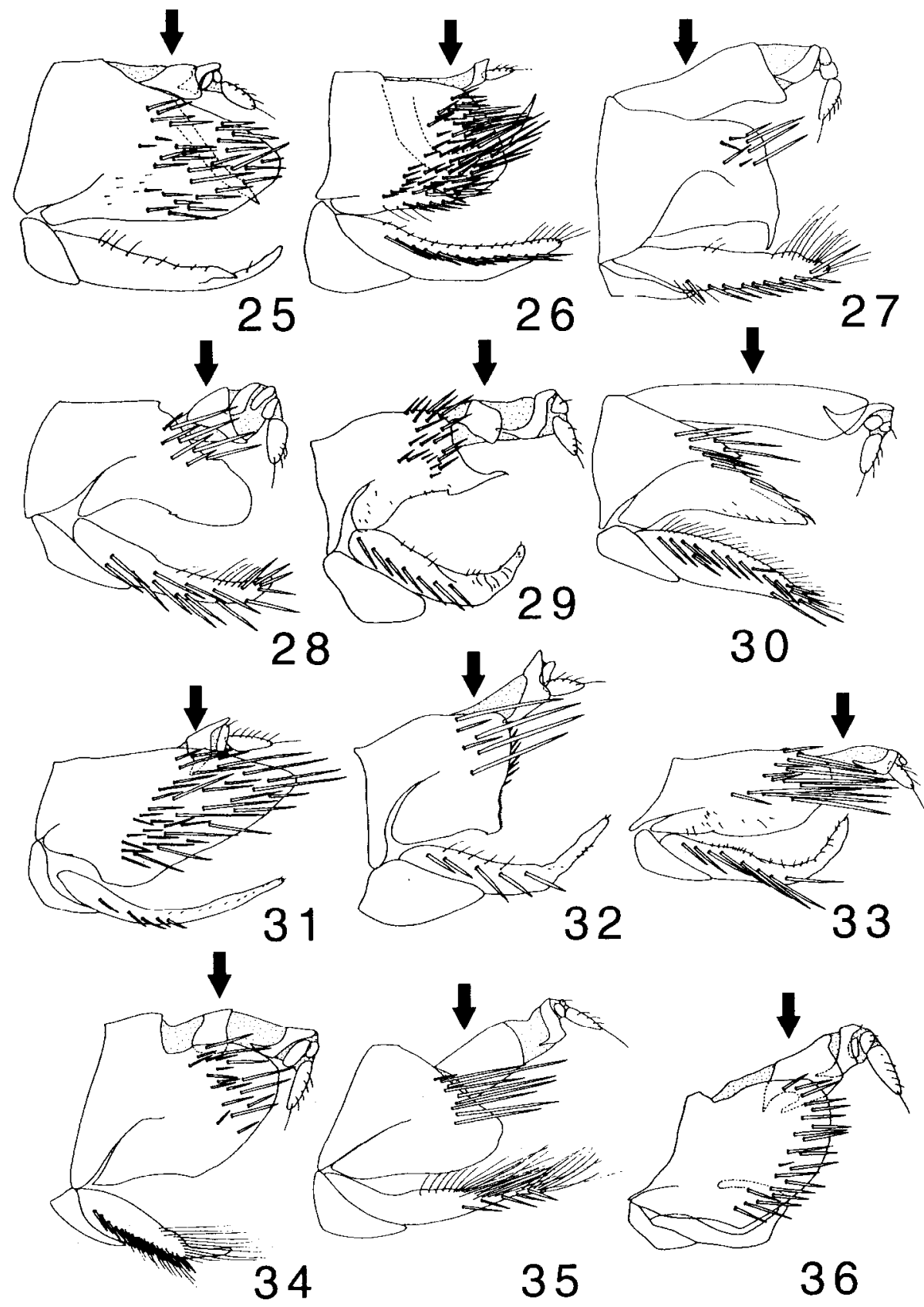

Figs. 25-36. Male genital and postgenital segments. 25, Orientus ishidae; 26, Paramesodes albinervosus; 27, Limotettix striola; 28, Scleroracus jakowleffi; 29, Balclutha incisa; 30, Elymana sulphurella; 31, Hecalus concentralis; 32, Macrosteles striifrons; 33, Yamatotettixflavovittatus; 34, Hishimonus sellatus; 35, Phlogotettix cyclops; 36, Japananus hyalinus. 

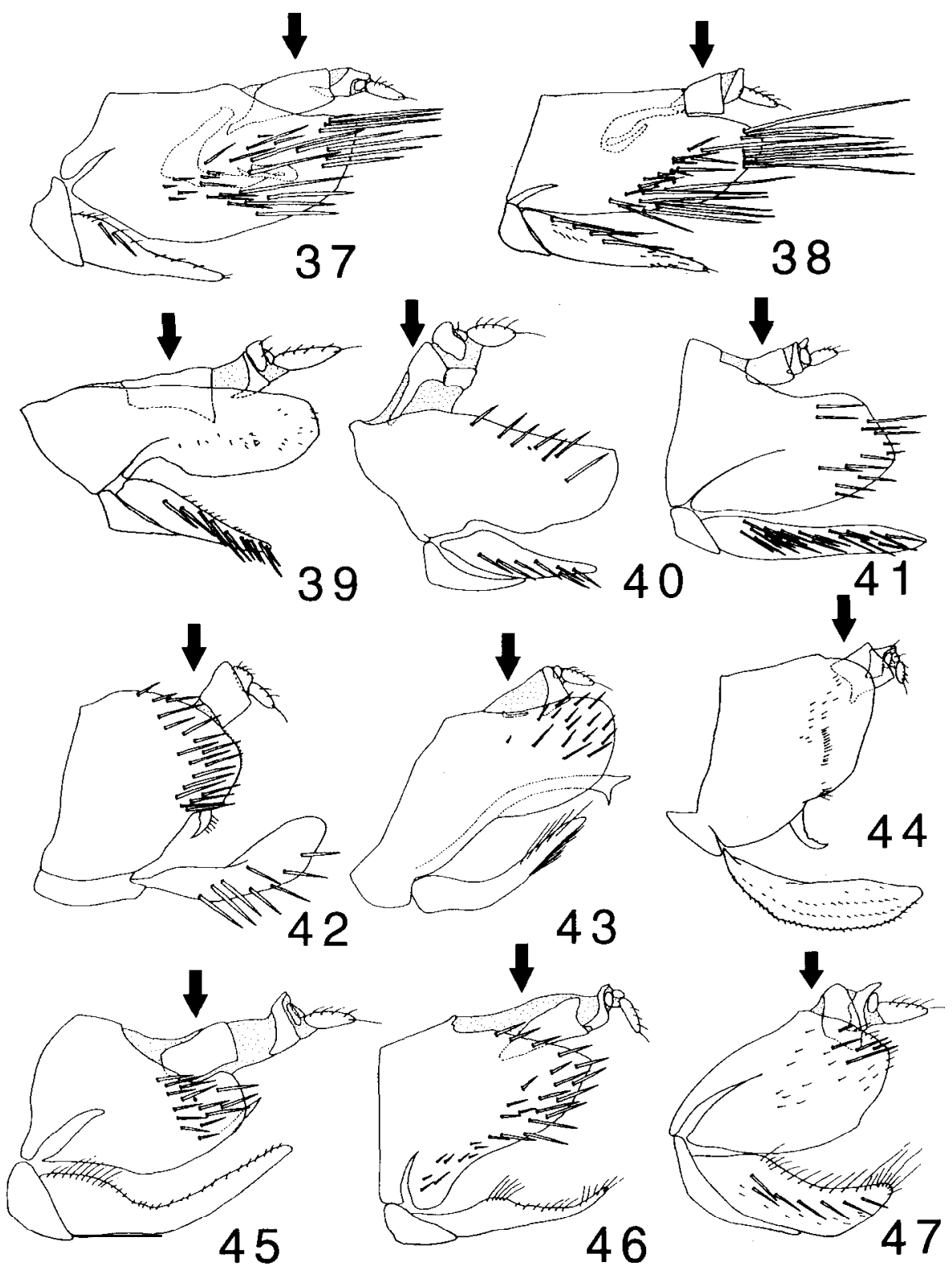

Figs. 37-47. Male genital and postgenital segments. 37, Scaphoideus albovittatus; 38, S. festivus; 39, Doratulina (D.) producta; 40, D. (Paivanana) indra; 41, Amimenus mojiensis; 42, Xestocephalus iguchii; 43, Batracomorphus mundus; 44, Planaphrodes sahlbergi; 45, Drabescus nigrifemoratus; 46, Parabolopona guttatus; 47, Penthimia nitida. 